Article

\title{
Why Do Some Evergreen Species Keep Their Leaves for a Second Winter, While Others Lose Them?
}

\author{
Peter J. Grubb ${ }^{1, *}$, Christine L. Thompson ${ }^{2}$ and Geoffrey H. Harper ${ }^{2}$ \\ 1 Department of Plant Sciences, University of Cambridge, Downing Street, Cambridge, \\ CB2 3EA, UK \\ 2 Royal Botanic Garden Edinburgh, 20A Inverleith Row, Edinburgh EH3 5LR, UK; \\ E-Mails: christinethomps@gmail.com (C.L.T.); g.harper@rbge.ac.uk (G.H.H.) \\ * Author to whom correspondence should be addressed; E-Mail: pjg12@cam.ac.uk; \\ Tel.: +44-1223-276-576.
}

External Editor: Eric J. Jokela

Received: 4 August 2014; in revised form: 21 October 2014 / Accepted: 24 October 2014 / Published: 30 October 2014

\begin{abstract}
In subtropical montane semi-moist forest in SW China (SMSF), a large majority of evergreen tree and tall shrub species was found to have only one cohort of old leaves in early spring. In contrast, almost all species of evergreen tree and tall shrub in warm temperate rain forest (WTRF) in Japan and sclerophylls in Mediterranean-climate forest (MSF) of the Mediterranean Basin have two or more cohorts of old leaves in early spring; they drop their oldest cohort during or soon after leaf outgrowth in spring. Japanese WTRF has no dry season and MSF a dry summer. SMSF has a dry winter. On four evergreen Rhododendron species from SW China with only one cohort of old leaves in spring when in cultivation in Scotland, the majority of leaves in the senescing cohort fell by the end of December. We hypothesize that with dry winters, there is an advantage to dropping older leaves in autumn, because there is a low chance of appreciable positive assimilation in winter and a high chance of desiccation, reducing the resorption of dry mass and mineral nutrients from ageing leaves. Our hypothesis may be extended to cover evergreens at high altitude or high latitude that experience cold soils in winter.
\end{abstract}

Keywords: leaf longevity; dry winters; Yunnan; subtropical montane semi-moist forest; Rhododendron 


\section{Introduction}

In the extensive literature on leaf longevity, scant attention has been paid to the question of why evergreen temperate plants and subtropical montane plants drop their old leaves when they do [1]. The current understanding of the advantage of having evergreen leaves in the temperate zones goes back to the seminal paper of Small [2], which provided a rationale in terms of leaves lasting for two or more growing seasons and did not consider the function of the leaves in the coolest months. He was concerned with plants of nutrient-poor soils and argued, in effect, that the evergreenness of many woody plants of nitrogen-poor soils in the Northern Hemisphere is incidental, and their advantage lies in keeping the leaves for two or more growing seasons. That enables the evergreen leaf to fix over its life-time more carbon per unit $\mathrm{N}$ than is possible for a deciduous species, even though the maximum instantaneous rate of fixation per unit $\mathrm{N}$ is lower in longer-lived leaves. The same argument can be applied to leaves in deep shade, where the return on unit $\mathrm{C}$ invested may be as important as that on unit $\mathrm{N}$. In the last forty years, this interpretation of the value of longer leaf-life has become generally accepted for plants on nutrient-poor soils and in deep shade and, to some extent, those of dry sites [1,3-7].

In this paper, we are concerned with the contrast in leaf persistence during winter between the evergreens in subtropical lower montane semi-moist forest (SMSF) and those in warm temperate rain forest (WTRF) and Mediterranean-climate sclerophyll forest (MSF). Evergreens in WTRF in Japan are known to suffer continual loss of leaves from a cohort [8], like trees in tropical lowland rain forest, where there is no cold or dry winter season [9]. However, as shown in Table 1, leaf fall in most species is concentrated in spring in the period during and after leaf expansion [10]; most species carry two or more cohorts of old leaves in the early-mid spring [8]. The situation is similar for sclerophylls in the Mediterranean Basin with leaf fall concentrated in the spring [4,11-15], although on some species, leaves last only one year at some sites (Table 2).

Table 1. Months of outgrowth of new leaves and of major leaf fall for species of tree and tall shrub in warm temperate rain forest (WTRF) in Japan over two years, 1994 and 1995 (from figure 4 of Nitta and Ohsawa [10]), and in Mediterranean-climate sclerophyll forest (MSF) in France from the text of Floret et al. [13]; the records in figure 3 of Castro-Díez and Montserrat-Martí [14] for Spain are similar to those of Floret et al. [13].

\begin{tabular}{|c|c|c|c|}
\hline Species & Family & $\begin{array}{l}\text { Months when new } \\
\text { leaves grew out }\end{array}$ & $\begin{array}{l}\text { Months in which leaf fall was } \\
\text { concentrated }\end{array}$ \\
\hline $\begin{array}{l}\text { WTRF Myrsine } \\
\text { neriifolia }\end{array}$ & Primulaceae & April-May & $\begin{array}{l}\text { April-June and } \\
\text { September-December }\end{array}$ \\
\hline Neolitsea sericea & Lauraceae & April-May & May-December \\
\hline Cleyera japonica & Pentaphylacaceae & April-May & July-October \\
\hline Symplocos prunifolia & Symplocaceae & April-May & Continuous \\
\hline Quercus salicina & Fagaceae & May & March-May \\
\hline Persea thunbergii & Lauraceae & May & $\begin{array}{l}\text { May-September } \\
\text { May-October (1995) }\end{array}$ \\
\hline Cinnamomum japonicum & Lauraceae & May & $\begin{array}{l}\text { May-June, August- September and } \\
\text { December-February (1994-1995) }\end{array}$ \\
\hline
\end{tabular}


Table 1. Cont.

\begin{tabular}{llll}
\hline Species & Family & $\begin{array}{l}\text { Months when new } \\
\text { leaves grew out }\end{array}$ & $\begin{array}{l}\text { Months in which leaf fall was } \\
\text { concentrated }\end{array}$ \\
\hline $\begin{array}{l}\text { Quercus acuta } \\
\text { Illicium religiosum }\end{array}$ & Fagaceae & May-June & $\begin{array}{l}\text { May-November } \\
\text { June-December }\end{array}$ \\
Eurya japonica & Pentaphylacaceae & $\begin{array}{l}\text { May-June } \\
\text { May-September and } \\
\text { December-February }\end{array}$ & $\begin{array}{l}\text { May-September and } \\
\text { November-February }\end{array}$ \\
MSF & & March-June & May-June \\
Myrtus communis & Myrtaceae & March-June & Not recorded * \\
Pistacia lentiscus & Anacardiaceae & March-June & May-June \\
Viburnum tinus & Adoxaceae & March-July & Peaks in spring \\
Pinus halepensis & Pinaceae & March-July & July-August \\
P. pinaster & Pinaceae & March-August & May-July \\
Buxus sempervirens & Buxaceae & April-May (+ some & May + September to December \\
Quercus ilex & Fagaceae & waves to September) & May-June \\
Arbutus unedo & Ericaceae & April-June & June-August \\
Quercus suber & Fagaceae & April-June & April-July \\
Phillyrea angustifolia & Oleaceae & April-August & May (+ some \\
Quercus coccifera & Fagaceae & August-September) & Mostly May-July \\
Rhamnus alaternus & Rhamnaceae & May-August & May-August \\
\hline
\end{tabular}

* June-October according to Montserrat-Martí and Pérez-Rontomé [15].

Table 2. Mean leaf longevities recorded for sclerophyll species in Greece [12], France [13] and Spain [16]; the longevities given in months in [12] and [13] have been converted to years, and all values reduced to no more than two significant figures.

\begin{tabular}{|c|c|c|c|}
\hline Species & $\begin{array}{c}\text { Mean leaf longevity } \\
\text { (year) determined } \\
\text { in Greece }\end{array}$ & $\begin{array}{c}\text { Mean leaf longevity } \\
\text { (year) determined } \\
\text { in Spain }\end{array}$ & $\begin{array}{c}\text { Range of longevity (year) } \\
\text { determined in France }\end{array}$ \\
\hline Pinus halepensis & & 3.1 & $2-3$, most $<2.5$ \\
\hline P. pinea & & 3.0 & \\
\hline$P$. pinaster & & 2.1 & (2) $-3+$, mostly $>3$ \\
\hline Quercus ilex & & 2.0 & $2-3$ \\
\hline Q. coccifera & 1.1 & 1.3 & $2.1-2.3$ \\
\hline Arbutus unedo & 1.2 & & $2(-3)$ \\
\hline \multicolumn{4}{|l|}{ Phillyrea } \\
\hline angustifolia & & & $2.1-2.2$ \\
\hline Pistacia lentiscus & 0.94 & & Not $>2$ \\
\hline Ceratonia siliqua & 2.0 & & \\
\hline Olea europaea & 2.0 & & \\
\hline Myrtus communis & 1.9 & & $1.1-1.2$ \\
\hline \multicolumn{4}{|l|}{ Buxus } \\
\hline sempervirens & & & $1-2$ \\
\hline Quercus suber & & 1.3 & $1.1-1.3$ \\
\hline Arbutus andrachne & 1.1 & & \\
\hline
\end{tabular}

In contrast to what has been reported for WTRF in Japan and MSF in the Mediterranean Basin, we have found for many of the evergreen trees and shrubs in SMSF that in early spring (April), there is only 
one cohort of old leaves present, while or before the new leaves expand, and there is no sign of ageing leaves about to fall. It appears that leaves drop after their second summer, but before the following spring. It is possible that they lose the leaves mostly in autumn. The suggested contrasting patterns of leaf fall are shown in Figure 1.

Figure 1. Theoretical patterns of seasonal change in the numbers of leaves in successive cohorts on evergreen trees with contrasting times of leaf fall related to different amounts of rainfall in winter.
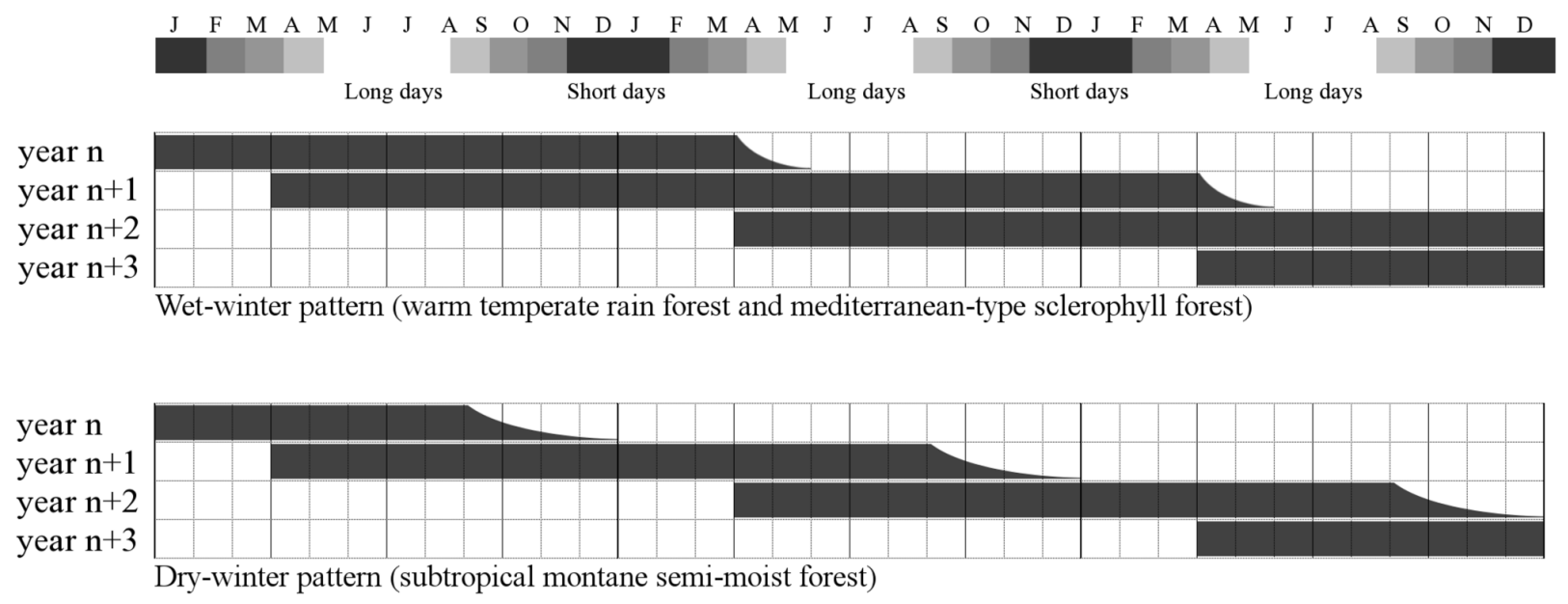

SMSF experiences a dry period from December to April in contrast to the WTRF of Japan and other areas where there is no strongly dry season [17], while in the Mediterranean Basin and other areas with a "Mediterranean-type" climate, the summer is dry (Figure 2). It seemed to us reasonable to relate the difference in the timing of leaf fall to the presence or absence of winter aridity.

Figure 2. Climate diagrams of the type introduced by Walter and Lieth [18] constructed for sites representative of subtropical montane semi-moist forest (Kunming, winter-dry), warm temperate rain forest (Fukuoka, no dry season) and Mediterranean-climate sclerophyll forest (Agrigento, summer-dry); for each site, altitude, mean annual temperature and mean annual rainfall are given at the top of the diagram; where mean monthly rainfall exceeds $100 \mathrm{~mm}$, the amount in excess of $100 \mathrm{~mm}$ is given using a compressed scale (one tenth of that used for values up to $100 \mathrm{~mm}$ ); the original data were taken from the WorldClim Global Climate Data website [19].
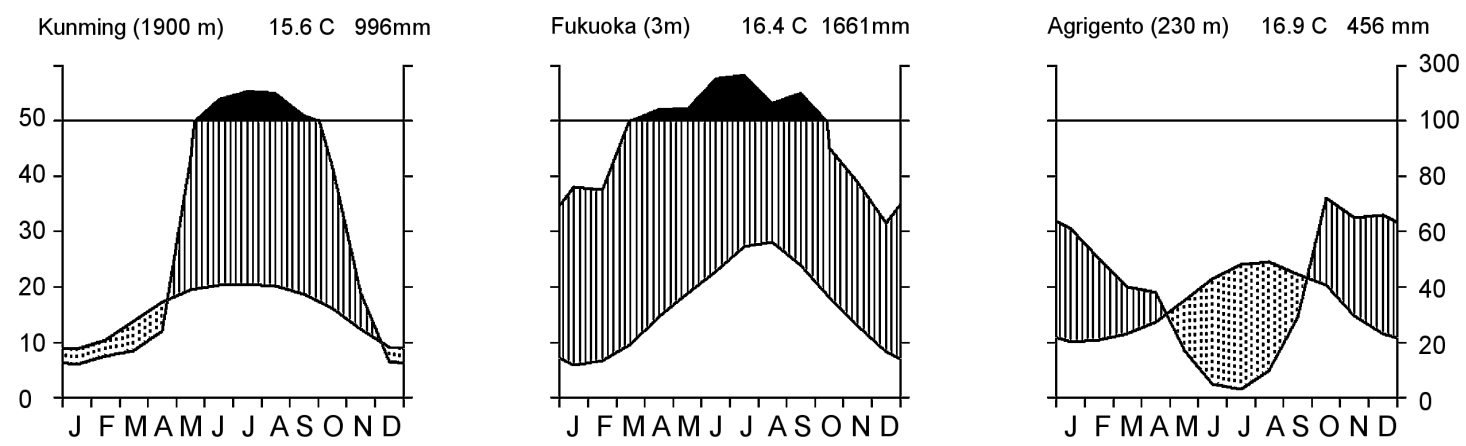
SMSF is found in Yunnan (SW China) between $23^{\circ} 20^{\prime}$ and $26^{\circ} 40^{\prime} \mathrm{N}$ at an altitude of 1300-2650 $\mathrm{m}$ [20] and was widespread before a large part of it was destroyed by humans. Song [21] reported that it resembles WTRF, but the leaves of the taller trees are more scleromorphic, while, in the ground layer, ferns are less abundant and less diverse, but graminoids and geophytes are more common. There are relatively fewer species of shade-tolerant small trees, treelets, climbers and vascular epiphytes. At the level of family and genus, there is a large overlap floristically with the WTRF of eastern China and Japan, but the Fagaceae are clearly dominant over the Lauraceae, and there are very few Rubiaceae in the understorey.

Our original observations were made in Yunnan in the spring of 2008, and they were followed up in 2009-2011 on plants from SW China in cultivation outdoors in Scotland. In this paper, we provide the first-ever reports on the timing of leaf fall in a range of evergreen species from SW China growing in Scotland. We also provide a testable multi-part hypothesis as to exactly how it could be advantageous for leaves in the SMSF to be shed during their second cool season before the water shortage reaches its peak intensity and why it is worthwhile for evergreens in WTRF and MSF to keep their leaves for a second winter despite the reduced irradiance and relatively low air temperatures. Finally, we consider parallels with leaf shedding by evergreens of cold temperate regions where the winter is not lacking in precipitation, but the soil becomes so cold that the uptake of water is inhibited, and air temperatures are very low. Species nomenclature follows the new Flora of China [22], and assignment to families follows the APweb site [23].

\section{Material and Methods}

\subsection{Observations in Yunnan}

Observations on the numbers of cohorts of old leaves were made at two different SMSF sites (on April 12 and 14, 2008). The first was adjacent to the Bamboo Temple (Qiungzhu si) near Kunming at ca. 2130-2150-m altitude (Longitude 102 $37^{\prime} 20^{\prime \prime} \mathrm{E}$, Latitude $25^{\circ} 04^{\prime} 12^{\prime \prime} \mathrm{N}$ ); the forest was mapped by $\mathrm{Wu}[20]$ as in his Castanopsis orthacantha formation. The second site was on the Jizu Shan, above the

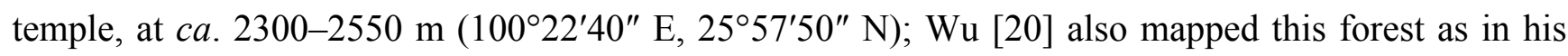
Castanopsis orthacantha formation, but actually it was dominated by C. delavayi, which is normally absent from the $C$. orthacantha formation and is characteristic of somewhat drier areas.

We made records for all of the evergreen species we could identify, which covered around 95\% of individual trees and tall shrubs. Records of the numbers of cohorts of leaves were made on a minimum of three trees or shrubs for almost all species and checked on larger numbers of trees or shrubs of the commonest species. Only a single plant of Osmanthus yunnanensis was found. The trees studied were chosen haphazardly while walking along paths through the forests. For almost all species (not Cyclobalanopsis glaucoides; see the Results), observations were confined to shoots up to $3 \mathrm{~m}$ above ground level. Separation of cohorts was based on ring scars on the stems, differences in the length of internodes and subtle differences in leaf colour. We report the two species that gave results that were inconsistent between the two sites and the one species on which it was impossible to separate cohorts confidently. 
Observations were also made in Rhododendron scrub with scattered Tsuga dumosa on south-facing slopes on the eastern side of the Cang Shan $\left(160^{\circ} 05^{\prime} 24^{\prime \prime}\right.$ E, $25^{\circ} 41^{\prime} 24^{\prime \prime}$ N) west of Dali at about 3100-3200 m, just above the secondary pine forest, which had replaced SMSF; here, we recorded the numbers of cohorts of leaves on five species of Rhododendron, including $R$. decorum, which is recorded by $\mathrm{Wu}[20]$ in four SMSF associations. Again at least three plants per species were studied.

\subsection{Initial Survey in Scotland}

We studied species of Rhododendron from Yunnan and adjacent provinces, partly because there is a large and critically labelled collection at the Royal Botanic Garden Edinburgh (the Inverleith site in Edinburgh and the regional garden at Benmore) and partly because it is the most speciose genus of woody plants in the SMSF. Wu [20] recorded nine species in his descriptions of 12 associations. The mean values of the blade lengths recorded for the nine species [24] are $1.9 \mathrm{~cm} R$. microphyton, $2.6 \mathrm{~cm}$ $R$. spiciferum, $5 \mathrm{~cm} R$. siderophyllum, $6.8 \mathrm{~cm} R$. spinuliferum, $8 \mathrm{~cm} R$. leptothrium, $8.5 \mathrm{~cm}$ $R$. moulmainense, $10.5 \mathrm{~cm} R$. irroratum, $11 \mathrm{~cm} R$. delavayi and $12 \mathrm{~cm} R$. decorum (overall mean: $7.4 \mathrm{~cm}$ ). The blade lengths of all nine species are short relative to the total range found in the genus in southern China: $0.5-45 \mathrm{~cm}$ [24].

Our initial survey covered all of the evergreen species of Rhododendron from SW China (Yunnan and/or Xizang and Sichuan) that we could find in a healthy state at Inverleith and/or Benmore. The Inverleith garden is in Edinburgh, and that at Benmore is $c a .110 \mathrm{~km}$ west and has a much higher rainfall. The annual mean for 1959-2010 was $2358 \mathrm{~mm}$ (range 1807-3067) at Benmore vs. $626 \mathrm{~mm}$ (range 436-908) at Inverleith; at both sites, the rainfall is fairly evenly distributed through the year. The two sites do not differ greatly in the incidence of air frost (48 days per year in 1971-2010 at Benmore vs. 52 days per year in 1959-2010 at Inverleith), but the lowest recorded temperature is not as low at Benmore as at Inverleith $\left(-10.0^{\circ} \mathrm{C} v s .-15.6^{\circ} \mathrm{C}\right)$. The higher rainfall makes it possible to grow many less drought-tolerant species at Benmore.

We studied 48 species in healthy condition at Benmore and 18 at Inverleith on June 2 and 3, 2009, respectively. Most of the species had been collected in types of forest or thicket wetter than SMSF, some having very large leaves, e.g., $R$. rex, $R$. seminoides, $R$. magnificum and $R$. praestans with mean lamina lengths of 25, 25, 26 and $27 \mathrm{~cm}$, respectively [24].

Except for one case of special interest, we report the cohort number only for those species that gave consistent results for at least three individuals. As with our observations in China, the separation of cohorts was based on ring scars on the stems, differences in the length of internodes and subtle differences in leaf colour.

We recognized four groups of species based on the number of cohorts of old leaves present, in addition to any new leaves expanding: those with more than three, three, two or one, respectively. Studies on the North American species, Rhododendron maximum, have shown that the loss of leaves of a given cohort can begin and finish gradually $[25,26]$. Thus, on the plants of species we assigned to the groups with two or more cohorts of old leaves, there were cases where some shoots had lost some of the leaves from the oldest cohort. Similarly, in the case of plants of species assigned to the group with one cohort of old leaves, some shoots had a few leaves left from the previous cohort. 
Twenty four species at Benmore, 6 at Inverleith and two studied at both sites yielded clear and consistent numbers of cohorts. The remaining species studied were too variable (from plant to plant or branch to branch) in the number of cohorts of mature leaves to be put in one of the four groups. For each of three species studied at Benmore, records were made for two subspecies; in all three species, the subspecies had different numbers of cohorts of old leaves.

\subsection{Critical Observations on Leaf Fall in Scotland}

Our critical study of the timing of leaf fall was confined to the Edinburgh (Inverleith) garden. Here, the winter is not lacking in rainfall as in the SMSF. As noted above, the annual mean rainfall was $626 \mathrm{~mm}$ in 1959-2010 (719 mm in 1981-2010), of which 32\% fell in the months December-March; at the Kunming weather station at 1891-m altitude (near the mean altitude of SMSF) in 1971-2000, it was $1011 \mathrm{~mm}$, of which 6\% fell in December-March. The annual mean air temperature at Inverleith is much lower than at the Kunming station $\left(8.2 v s .14 .6^{\circ} \mathrm{C}\right)$, and likewise, the mean maximum air temperature of the hottest month $19.1^{\circ} \mathrm{C}$ (July) vs. $24.6^{\circ} \mathrm{C}$ (May). However, the mean minimum air temperature in the coldest month (December in both cases) is very similar at the two sites $\left(1.3{ }^{\circ} \mathrm{C}\right.$ Inverleith, $1.5{ }^{\circ} \mathrm{C}$ Kunming). The absolute minimum air temperature recorded at Inverleith is appreciably lower than that recorded at Kunming $\left(-15.6{ }^{\circ} \mathrm{C} v s .-7.8^{\circ} \mathrm{C}\right)$.

We do not know the relative importance of lower temperatures, shortened day-length and leaf desiccation in triggering the fall of old leaves in Yunnan. However, we think it likely that the first two factors have the greatest impact, because in that case the leaves can fall before any problems arise with the resorption of nutrients from dried tissues. The results of our study can be only suggestive of what happens in Yunnan, but we expect that similar results will be found in due course for plants in their native habitats.

The five species that we used are in five different subsections of Rhododendron and in three different subgenera, and all are native to SW China (Table 3). Rhododendron rubiginosum was chosen because we saw it in China and in Scotland with only one cohort of old leaves in early spring; $R$. decorum was chosen because we saw it in China and in Scotland with one cohort of old leaves in early spring on some shoots and two cohorts on others and because it was recorded by $\mathrm{Wu}$ [20] in SMSF.

$R$. pubescens was chosen because it belongs to subsection Scabrifolia, which is especially well represented in the drier parts of SW China, and because it is closely related to R. spiciferum. The latter was recorded by $\mathrm{Wu}[19]$ in two SMSF associations, and we saw it in China to have only one cohort of old leaves in the spring. $R$. wallichii and $R$. wardii were chosen because in Scotland they had only one cohort of old leaves at the time when new leaves were expanding.

Three healthy shrubs of each species were used. As shown in Table 3, for two species, all three individuals came from material collected in Yunnan, and for another two species, one came from Yunnan and the other two from an adjacent province (SW Sichuan or SE Xizang). For only one species (R. wallichii) did the material come from further west (Bengal and Nepal).

On June 15-17, 2009, three well-lit healthy shoots were marked with a discreet tag, and the leaves in the cohort preceding the most recent one were counted. The mean number of leaves per shoot in the study cohort varied with species from 4.88 to 9.44 , and therefore, the total number of leaves per species 
from 44 to 85 (Table 3). Thereafter, shoots were recorded at weekly intervals until January 5, 2011, by which time all but three of the 314 studied leaves had fallen. Two shoots on one plant of R. decorum died in December, 2009-January, 2010, bringing the number of study leaves for that species to 54 .

Table 3. The subgenera, subsections and natural distributions of the species of Rhododendron growing in the Royal Botanic Garden Edinburgh at Inverleith used for monitoring the timing of leaf loss, the provenances of the three plants used per species and mean numbers of leaves studied per shoot; nomenclature and subgeneric assignments follow Fang et al. [24].

\begin{tabular}{|c|c|c|c|c|}
\hline Species & $\begin{array}{l}\text { Subgenus and } \\
\text { subsection }\end{array}$ & $\begin{array}{c}\text { Natural } \\
\text { distribution * }\end{array}$ & Provenance & $\begin{array}{c}\text { Mean number of } \\
\text { leaves studied per } \\
\text { shoot }\end{array}$ \\
\hline $\begin{array}{l}\text { R. decorum ssp. } \\
\text { decorum }\end{array}$ & $\begin{array}{l}\text { Hymenanthes: } \\
\text { Fortunea }\end{array}$ & $\mathrm{G}, \mathrm{S}, \mathrm{X}, \mathrm{Y} ; \mathrm{M}$ & $\begin{array}{l}2 \text { NW Yunnan } \\
1 \text { W Yunnan }\end{array}$ & $\begin{array}{c}8.0 \text { (reduced by shoots } \\
\text { dying to } 6.0 \text { ) }\end{array}$ \\
\hline R. pubescens & $\begin{array}{c}\text { Pseudorhodorastrum: } \\
\text { Scabrifolia }\end{array}$ & $\mathrm{S}, \mathrm{Y}$ & 3 Yunnan & 9.4 \\
\hline $\begin{array}{l}\text { R. rubiginosum var. } \\
\text { rubiginosum }\end{array}$ & $\begin{array}{l}\text { Rhododendron: } \\
\text { Heliolepida }\end{array}$ & $\mathrm{S}, \mathrm{X}, \mathrm{Y} ; \mathrm{M}$ & $\begin{array}{l}1 \text { NW Yunnan } \\
2 \text { SW Sichuan }\end{array}$ & 9.4 \\
\hline R. wallichii & $\begin{array}{l}\text { Hymenanthes: } \\
\text { Campanulata }\end{array}$ & $\mathrm{X} ; \mathrm{B}, \mathrm{I}, \mathrm{N}, \mathrm{S}$ & $\begin{array}{l}1 \text { Bengal } \\
2 \text { Nepal }\end{array}$ & 4.9 \\
\hline $\begin{array}{l}\text { R. wardii var. } \\
\text { wardii }\end{array}$ & $\begin{array}{l}\text { Hymenanthes: } \\
\text { Campylocarpa }\end{array}$ & $\mathrm{S}, \mathrm{X}, \mathrm{Y}$ & $\begin{array}{l}1 \text { W Yunnan } \\
2 \text { SE Xizang }\end{array}$ & 5.1 \\
\hline
\end{tabular}

* Chinese provinces: G, Guizhou; S, Sichuan; X, Xizang; Y, Yunnan. Other countries: B, Bhutan; I, India; M, Myanmar; N, Nepal, S, Sikkim.

Regarding changes in leaf colour during senescence, a check was made at the start; only $R$. wallichii and $R$. wardii had any leaves turning from green to yellow or brown (two out of 44 and three out of 46, respectively). The number of leaves on each shoot at least partially changed from green was registered at each recording. For those species and individual shrubs on which leaves lost their green colour at least partially before dropping, we obtained an estimate of how long individual leaves remained on the plant in a partially non-green condition. We assumed that on any given shoot, no leaf fell before it ceased to be wholly green. Thus, for example, if there were four green and two no longer wholly green ones on a shoot at Time 1, then only two green and two not wholly green ones at Time 2, we assumed that the two that were not wholly green at Time 1 had fallen off, while two of the four that were green at Time 1 had turned not wholly green.

\section{Results}

\subsection{Observations on Cohort Number in Yunnan}

At the SMSF sites, thirteen species in eight families were seen with only one cohort of old leaves in mid-April, and seven of these had new leaves beginning to expand (Table 4). In contrast, only five species in four families spread over the two study sites were recorded consistently with two cohorts of 
old leaves, and only one with three cohorts (Table 4); only one of these six species had new leaves expanded.

Table 4. Numbers of cohorts of old leaves recorded on most shoots of evergreen tree and shrub species at two sites in subtropical montane semi-moist forest and at one site in Rhododendron scrub in Yunnan in mid-April 2008; species that also had some very young leaves are marked with an asterisk.

\begin{tabular}{|c|c|c|}
\hline Family & Species & Site \\
\hline \multicolumn{3}{|l|}{ One cohort } \\
\hline Araliaceae & Metapanax delavayi* & 2 \\
\hline \multirow[t]{5}{*}{ Ericaceae } & Rhododendron spiciferum & 1 \\
\hline & R. cyanocarpum & 3 \\
\hline & R. racemosum & 3 \\
\hline & R. rubiginosum & 3 \\
\hline & R. xanthostephanum & 3 \\
\hline \multirow[t]{4}{*}{ Fagaceae } & Castanopsis orthacantha* & 3 \\
\hline & Lithocarpus dealbatus* & 1 \\
\hline & Castanopsis delavayi & 1 \\
\hline & Lithocarpus variolosus & 2 \\
\hline Myricaceae & Myrica nana* & 2 \\
\hline Oleaceae & Osmanthus yunnanensis & 1 \\
\hline \multirow[t]{2}{*}{ Pentaphylacaceae } & Eurya cf. nitida* & 2 \\
\hline & Ternstroemia gymnanthera* & 2 \\
\hline Sabiaceae & Meliosma yunnanensis & 2 \\
\hline \multirow[t]{2}{*}{ Theaceae } & Schima argentea & 2 \\
\hline & Schima sp.* & 1 \\
\hline \multicolumn{3}{|l|}{ Two cohorts } \\
\hline Buxaceae & Sarcococca hookeriana & 2 \\
\hline \multirow[t]{2}{*}{ Ericaceae } & $\begin{array}{l}\text { Craibiodendron } \\
\text { yunnanense* }\end{array}$ & 1 \\
\hline & Pieris formosa & 1 \\
\hline Magnoliaceae & Michellia yunnanensis & 1 \\
\hline Rosaceae & Laurocerasus cf. zippeliana & 1 \\
\hline \multicolumn{3}{|l|}{ Three cohorts } \\
\hline Theaceae & Camellia pitardii & 2 \\
\hline
\end{tabular}

'Sites: 1 = Castanopsis orthacantha formation near Kunming; 2 = Castanopsis delavayi formation on the Jizu Shan; 3 = Rhododendron scrub on the Cang Shan; for details of these sites see Materials and Methods.

For one species at Site 1, Cyclobalanopsis glaucoides (Fagaceae), we examined the whole crowns with binoculars; they had on some branches only newly expanded leaves and, on others, one cohort of senescing leaves plus newly expanding leaves; it seems likely that for most of the year, this species carries only one cohort of leaves.

Two common species varied in the number of cohorts of old leaves (one or two) between the two sites: Myrsine africana (Primulaceae) and Viburnum cylindricum (Adoxaceae). In Vaccinium cf. sprengelii (Ericaceae), it was not possible to separate cohorts confidently. 
At the Rhododendron scrub site, four of the five evergreen species were found to have only one cohort of old leaves (Table 4); on the fifth, $R$. decorum, some shoots had only one cohort of old leaves, but others carried two.

\subsection{Observations on Cohort Number in Scotland}

Of the 35 species and subspecies for which we obtained clear results, 16 (47\%) lost their oldest cohort of leaves before the new ones expanded and possibly did so months earlier (Table 5). The mean length of the leaf blade of species that had only one cohort of old leaves in spring is appreciably smaller than that of species with two such cohorts and that of those with three such cohorts: $6.1 \pm 0.80$ (SEM) cm vs. $12.9 \pm 2.3$ and $13.5 \pm 2.9$. The significance of the differences in mean length of leaf blade among the three groups was tested using ANOVA: $F=5.536 ; p=0.0088$. Tukey tests revealed the following probabilities for comparisons between groups: one cohort $v s$. two $p=0.014$, one cohort $v s$. three $p=0.062$, and two cohorts $v s$. three $p=0.985$.

Table 5. The normal maximum longevity of leaves of Rhododendron species from SW China growing at Benmore (most species) and/or Inverleith, based on observations made on June 2-3, 2009, together with mean leaf blade lengths and distributions taken from Fang et al. [24]; (BI), studied at Benmore and Inverleith; (I), studied at Inverleith; abbreviations of provinces; G, Guizhou; S, Sichuan; X, Xizang; Y, Yunnan.

\begin{tabular}{|c|c|c|c|c|}
\hline $\begin{array}{l}\text { Species, subspecies } \\
\text { and variety }\end{array}$ & $\begin{array}{l}\text { Mean length of leaf } \\
\text { blade }(\mathrm{cm})\end{array}$ & $\begin{array}{l}\text { Usual lower } \\
\text { altitudinal limit (m) }\end{array}$ & $\begin{array}{c}\text { Usual upper } \\
\text { altitudinal } \\
\text { limit (m) }\end{array}$ & $\begin{array}{c}\text { Provinces } \\
\text { where recorded }\end{array}$ \\
\hline \multicolumn{5}{|l|}{ Leaves lasting $>3$ years } \\
\hline R. strigillosum & 12.0 & 1600 & 3800 & $\mathrm{~S}, \mathrm{Y}$ \\
\hline \multicolumn{5}{|l|}{$\begin{array}{l}\text { Three cohorts of old } \\
\text { leaves present in spring }\end{array}$} \\
\hline R. faucium & 8.0 & 2600 & 3400 & $\mathrm{X}$ \\
\hline R. rieri $(\mathrm{I})$ & 10.3 & 1700 & 1800 & $\mathrm{~S}$ \\
\hline R. insigne & 10.5 & 700 & 2000 & S \\
\hline R. arizelum & 14.0 & 2500 & 4000 & $\mathrm{X}, \mathrm{Y}$ \\
\hline R. rex ssp. rex & 24.5 & 2300 & 3300 & $\mathrm{~S}, \mathrm{Y}$ \\
\hline $\begin{array}{l}\text { Two cohorts of old } \\
\text { leaves present in spring }\end{array}$ & & & & \\
\hline $\begin{array}{l}\text { R. haematodes ssp. } \\
\text { haematodes }\end{array}$ & 5.1 & 3200 & 4000 & $\mathrm{Y}$ \\
\hline $\begin{array}{l}R \text {. dichroanthum ssp. } \\
\text { apodectum }\end{array}$ & 5.5 & 2600 & 3600 & Y \\
\hline $\begin{array}{l}R . \text { sanguineum var. } \\
\text { sanguineum }\end{array}$ & 5.9 & 2800 & 4300 & $\mathrm{X}, \mathrm{Y}$ \\
\hline $\begin{array}{l}R . \text { neriiflorum ssp. } \\
\text { neriiflorum }\end{array}$ & 6.5 & 2500 & 3600 & $X, Y$ \\
\hline R. piercei & 7.5 & 3900 & 4200 & $\mathrm{X}$ \\
\hline R. sperabile $(\mathrm{I})$ & 9.1 & 2600 & 4200 & $\mathrm{Y}$ \\
\hline
\end{tabular}


Table 5. Cont.

\begin{tabular}{|c|c|c|c|c|}
\hline $\begin{array}{c}\text { Species, subspecies and } \\
\text { variety }\end{array}$ & $\begin{array}{l}\text { Mean length of leaf } \\
\text { blade (cm) }\end{array}$ & $\begin{array}{c}\text { Usual lower } \\
\text { altitudinal limit (m) }\end{array}$ & $\begin{array}{c}\text { Usual upper } \\
\text { altitudinal } \\
\text { limit (m) }\end{array}$ & $\begin{array}{c}\text { Provinces } \\
\text { where recorded }\end{array}$ \\
\hline R. bureavi & 10.0 & 2800 & 4500 & $\mathrm{~S}, \mathrm{Y}$ \\
\hline $\begin{array}{l}R \text {. arboreum ssp. } \\
\text { arboreum }\end{array}$ & 10.5 & 1500 & 3600 & $\mathrm{X}$ \\
\hline R. argyrophyllum & 10.5 & 1600 & 2300 & $\mathrm{G}, \mathrm{S}, \mathrm{Y}$ \\
\hline R. seminoides & 20.5 & 3500 & 3900 & $\mathrm{X}, \mathrm{Y}$ \\
\hline R. rex ssp. fictolacteum & 24.5 & 2900 & 4000 & S, X, Y \\
\hline R. magnificum & 26.0 & 1800 & 2400 & $\mathrm{X}$ \\
\hline R. praestans & 26.5 & 3100 & 4200 & $\mathrm{X}, \mathrm{Y}$ \\
\hline \multicolumn{5}{|l|}{$\begin{array}{l}\text { Only one cohort of } \\
\text { old leaves } \\
\text { present in spring }\end{array}$} \\
\hline R. pubescens (I) & 2.2 & 2000 & 2600 & $\mathrm{~S}, \mathrm{Y}$ \\
\hline R. hemitrichotum (I) & 2.3 & 2200 & 4000 & $\mathrm{~S}, \mathrm{Y}$ \\
\hline R. fletcherianum & 3.8 & 3400 & 3400 & $\mathrm{X}, \mathrm{Y}$ \\
\hline R. davidsonianum & 4.3 & 1500 & 2800 & $\mathrm{~S}$ \\
\hline R. searsiae & 4.3 & 2300 & 3300 & $\mathrm{~S}$ \\
\hline R. concinnum & 5.0 & 2300 & 3000 & $\mathrm{G}, \mathrm{S}, \mathrm{Y}$ \\
\hline R. siderophyllum (I) & 5.0 & 1800 & 3000 & $\mathrm{G}, \mathrm{S}, \mathrm{Y}$ \\
\hline R. thomsonii & 5.0 & 3000 & 4000 & $\mathrm{X}$ \\
\hline $\begin{array}{l}\text { R. haematodes ssp. } \\
\text { chaetomallum }\end{array}$ & 5.1 & 3100 & 4000 & $\mathrm{X}, \mathrm{Y}$ \\
\hline $\begin{array}{l}\text { R. rubiginosum var. } \\
\text { rubiginosum }(\mathrm{BI})\end{array}$ & 5.8 & 2800 & 3600 & $\mathrm{~S}, \mathrm{X}, \mathrm{Y}$ \\
\hline R. cerasinum & 6.5 & 3200 & 3800 & $\mathrm{X}$ \\
\hline R. wardii (I) & 6.5 & 3000 & 4600 & S, X, Y \\
\hline R. heliolepis & 8.5 & 3000 & 3700 & $\mathrm{~S}, \mathrm{X}, \mathrm{Y}$ \\
\hline $\begin{array}{l}R . \text { neriiflorum ssp. } \\
\text { appropinquans }\end{array}$ & 9.5 & 2100 & 3600 & $\mathrm{X}, \mathrm{Y}$ \\
\hline R. wallichii $(\mathrm{BI})$ & 9.5 & 3000 & 4300 & $\mathrm{X}$ \\
\hline R. sidereum & 15.0 & 2400 & 3400 & $\mathrm{Y}$ \\
\hline
\end{tabular}

3.3. Observations on the Timing of Leaf Fall and Leaf Senescence in Scotland

\subsubsection{Leaf fall}

The time courses of cumulative leaf fall are plotted in Figure 3. For R. rubiginosum, appreciable fall did not begin until October, but most leaf loss occurred by the end of December. For R. pubescens, the fall began earlier (July) and finished later (June), but the highest rate of fall occurred in November-December. For $R$. wardii and $R$. wallichii, there was a relatively high and rather steady rate of fall from July to November. Only a modest proportion of leaves fell from $R$. decorum in the autumn, and that loss occurred in October-November. 
Figure 3. Timing of leaf fall and loss of green colour for five species of Rhododendron from SW China grown in Edinburgh; the numbers of leaves in marked cohorts were followed from their second summer; in each graph, the upper line is for green leaves plus non-green leaves and the lower for green leaves. (a) R. rubiginosum; (b) R. pubescens; (c) R. wallichii; (d) $R$. wardii and (e) R. decorum.
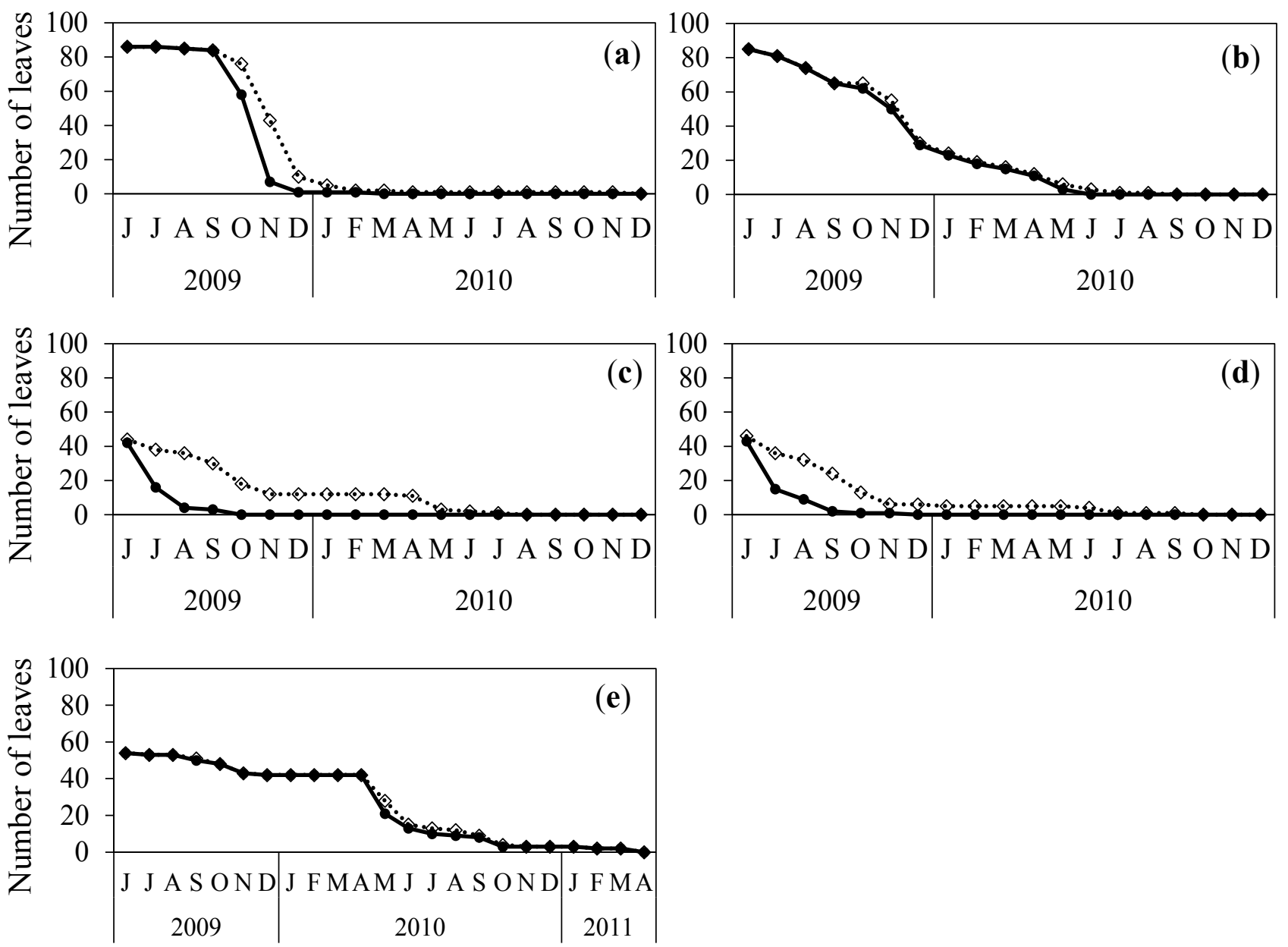

By December 30, 2009, R. rubiginosum had lost 76/86 leaves (88\%), R. wardii 40/46 leaves (87\%), R. wallichii 32/44 (73\%), R. pubescens 55/85 (65\%) and R. decorum 12/54 (22\%). Ninety-five percent of leaves had fallen by February 3, 2010, for $R$. rubiginosum, by June 9 for $R$. pubescens and $R$. wallichii, by July 14 for $R$. wardii and by November 10 for $R$. decorum .

\subsubsection{Changes in Leaf Colour}

The five study species differed in whether or not the leaves generally lost their green colour before falling. A large majority of the leaves of $R$. pubescens (66/85) were still green when they fell, and the same was true of a little under a half of those of $R$. decorum (23/54), while for both species the rest of the leaves had turned brown. On R. rubiginosum, most of the leaves turned yellow-brown to brown before falling (at least 73/86), while in $R$. wallichii and $R$. wardii they almost all became mottled yellow-brown to brown (at least $41 / 44$ and $42 / 46$, respectively).

The estimated length of time spent by leaves at least partially yellow-brown or brown before they fell differed markedly among the species. The mean number of weekly censuses at which a leaf was recorded 
as no longer wholly green was 3.1 for R. decorum, 3.5 for $R$. rubiginosum, 4.4 for $R$. pubescens, 12.8 for $R$. wardii and 18.7 for $R$. wallichii; the median number was two for $R$. decorum and $R$. rubiginosum, four for $R$. pubescens, eight for $R$. wardii and 11 for $R$. wallichii. However, on all of the last three species, the leaves fell into two groups: those lasting in at least partially yellow-brown or brown state for $<20$ weekly censuses, and those lasting for 40 or more. The mean number of censuses for the shorter-lived group was 3.0 for R. rubiginosum ( 72 leaves), 7.6 for $R$. wardii (37) and 8.4 for $R$. wallichii (29). The mean for the longer-lived leaves was 40.0 for $R$. rubiginosum (one leaf), 51.6 for $R$. wardii (five) and 43.6 for $R$. wallichii (12).

\section{Discussion}

\subsection{Leaf Behaviour Established So Far}

Observations on a high proportion of the most abundant evergreen broad-leaved tree and shrub species in the SMSF of southern Yunnan found that 13/19 had only one cohort of old leaves in the spring (Table 4). To these, we can add one more genus and family on the evidence of the photograph of Skimmia multinervia (Rutaceae) on p. 198 of Lancaster [27] taken in the remains of SMSF on the Cang Shan. There is a marked contrast between these results and those for WTRF for which we know that the leaves of most evergreen species last two or more years [8], and in most of the 11 species in Table 1, leaf fall either began in the same month as the outgrowth of new leaves $(5 / 11)$ or one month later $(2 / 11)$ or two months later (1/11). In one of 11 species leaf fall began two months before outgrowth of new leaves, and in one species leaf fall was continuous throughout the year. Only in Cleyera japonica was there a pattern even somewhat like that found for Rhododendron species in cultivation in Scotland and suspected for many species in other families in SMSF in Yunnan: leaf fall not starting until July and continuing into October. None of the 12 MSF species of sclerophyll in Table 1 and none of the 14 in Table 2 has major leaf fall in late autumn-early winter. The only Mediterranean taxa reported to have that timing of leaf fall are the small shrub, Daphne gnidium [13] and Pistacia x saportae, the hybrid of evergreen $P$. lentiscus and deciduous $P$. terebinthus [15]. Even if a wider survey were to yield a lower proportion of species in SMSF with only one cohort of old leaves in early spring than 14/20 (70\%), there would clearly be a marked difference from the situation in WTRF and MSF where such species are very few.

Our survey of a non-random sample of Rhododendron species from a wide range of forest and thicket types in SW China growing in Scotland also showed that many lose the oldest cohort of leaves well before new ones expand: $46 \%$ of the 35 species and subspecies that yielded clear and consistent results. The species with only one cohort of old leaves in the spring had significantly smaller leaves than those with two or more cohorts. The mean blade length was $6.1 \mathrm{~cm}$ (Table 5), close to the mean for the nine species of Rhododendron reported by Wu [20] in SMSF (7.4 cm). These observations suggest that both small leaf size and leaf fall before winter are characteristic of winter-dry areas. There is huge variation in climate and vegetation type in SW China, and the larger-leaved species of Rhododendron, found to have more than one cohort in early spring when growing in Scotland, are found at sites not subject to winter drought [20] or protected by the topographic effects from it [27].

Our detailed observations on leaf fall of Rhododendron species in Scotland for more than a year are particularly significant because, for two of the five species, the number of cohorts in early spring was as 
we had recorded in China. Our records for four of the species studied in Scotland have provided the first-ever precise information on the timing of leaf fall among evergreen species that lose all or almost all of their oldest leaves before new ones expand, as seen in the second pattern in Figure 1.

The only other studies of leaf phenology in Rhododendron that we have found are those for $R$. maximum [25,26], which grows in eastern North America. Leaf fall was concentrated in July-August one year and more spread out in the following year: June-July and September-November when records ceased. There was no obvious explanation in terms of weather; there was a dry spell in the first year, but that came after most leaf fall had occurred. The year-to-year variation thus revealed should make us cautious, but at least it is clear that in both years the leaves of the oldest cohort fell after the expansion of new leaves had occurred.

We have found that there is not only a wide range of leaf behaviour in evergreen species of the genus Rhododendron in SW China (the number of cohorts of old leaves in the spring varying from one to $>3$ ), but also a continuum. This was shown by the species on which the numbers of cohorts of old leaves in the spring varied between individual plants and/or between branches on individual plants and by the differences between species in the timing of leaf loss (Figure 3). Our studies were all made on well-lit individuals, and it may well be that in at least some species, leaves remain longer on shaded plants than on well-lit ones, as found in WTRF in Japan $[8,10]$ and for Rhododendron maximum in eastern North America [25,26].

Despite the continuum, it is striking that so many species of evergreen in SW China do lose their oldest leaves before the expansion of new leaves, and, if our limited study of the timing of leaf fall in Scotland is a true guide, they lose them before leaf desiccation resulting from winter drought being likely to become severe. Obviously, new work on the timing of leaf fall in SMSF in China is needed, preferably linked to studies on changes in leaf water content, leaf colour and nutrient resorption. Meanwhile, we set out a multi-part hypothesis to explain how the early leaf fall could be advantageous.

\subsection{Hypothesis Proposed}

We hypothesize that in areas with dry winters, there is a net advantage to dropping the oldest cohort of leaves in autumn because: (1) there is a low chance of appreciable positive net assimilation in winter, and the loss of water by older leaves would outweigh the value of any positive net assimilation; and (2) there is a high chance of desiccation, reducing the effectiveness of the resorption of dry mass and mineral nutrients from ageing leaves. In contrast, where the winter is moist, there is a net advantage to retaining the oldest cohort of leaves, because there will be, in most years, a significant chance of positive net assimilation with no concurrent risk of leaf desiccation and, in almost all years, little risk of resorption being inhibited by leaf-desiccation.

With a single exception (see below), there has been no relevant observational or experimental work on SMSF species, but there have been several relevant studies on species in WTRF, MSF and related vegetation types.

For evergreen broad-leaved species in WTRF [28,29] and MSF [30,31], there is evidence from short-term observations that net assimilation during daylight is positive in winter. For sclerophylls, corroboration that net assimilation over the 24-hour cycle is positive, when it is too cool for extension growth, comes from the finding that the concentrations of non-structural carbohydrates in the leaves and 
branch wood increase during the winter [32,33]. This longer-term positive net assimilation occurs despite short-term damage to the photosynthetic system on the rare days with temperatures just below $0{ }^{\circ} \mathrm{C}[34,35]$.

Studies on various vegetation-types have found that drought often reduces respiration less than it reduces photosynthesis [36], and some have found that the respiration rate is not reduced by drought in all species [37]. Indeed, there is mounting evidence of increases in respiration as a result of drought [38,39], so that the possibility of negative net assimilation during dry periods has to be taken seriously. It may also be of value to a tree to reduce its leaf mass in such a way that it is easier to maintain a favourable water status (and, as a result, a favourable carbon balance) in the remaining leaves.

The value of the transfer of both dry mass and nitrogen from senescing leaves to newly expanding leaves has been documented for evergreen trees and shrubs in Japanese WTRF [40,41]. In Ternstroemia gymnanthera, a species also widespread in SMSF in Yunnan, the foliar concentration of $\mathrm{N}$ decreased during senescence by about 40\% [40]. Regarding sclerophylls in MSF, resorption of $\mathrm{N}$ can reach 48\% in Quercus suber [4]. Clearly, we need measurements for the dominant oaks (species of Castanopsis and Lithocarpus) in SMSF in Yunnan. We have not found work on the inhibition of resorption by desiccation during dry spells for species of WTRF or MSF, but in the North American deciduous shrub, Viburnum acerifolium [42], the decrease in P per unit leaf area during senescence can be $50 \%-100 \%$ inhibited by drought and that of $\mathrm{N}$ per unit area up to $60 \%$.

Our finding that on some Rhododendron species in cultivation many of the leaves fell while wholly green suggests that in them, resorption of major nutrients was minimal in extent. We need to know if these species behave in the same way in the field. If they do, then for them, our hypothesis simplifies to a concern for carbon balance.

Testing our hypothesis is not straightforward, because no test can be made in late winter on leaves that have fallen in the autumn. We suggest that a reasonable test would be to find out in a field experiment whether appropriate levels of leaf desiccation do reduce net assimilation to zero or negative values in (1) leaves between one and two years old in early to mid-autumn before they fall; and (2) leaves in their first year in late winter. The sensitivity of the resorption of nutrients would have to be tested on the leaves between one and two years old in early to mid-autumn. Only when these experiments have been made can we assess the likelihood that our hypothesis has identified the major selection pressures for early leaf fall. The observations and experiments should be made on species that keep their leaves until the third summer, as well as species that drop them after the second summer.

\subsection{Wider Application of the Hypothesis}

Our concern so far has been with evergreens subject to water shortage in winter, because of a paucity of rainfall, but other evergreens are subject to water shortage in winter, because the soil is so cold, that uptake becomes difficult, partly as a result of the viscosity of water being increased substantially and partly because the permeability of the root cell membranes is reduced a great deal [43]. We have in mind low to medium-height evergreen shrubs with small or very small leaves and evergreen conifers, growing in high latitudes or at high altitudes. For such plants, a further reason for 
dropping leaves soon after their second or third summer is that temperatures in winter may be so low that there is negligible net assimilation.

Karlsson [44] found that the mean expected leaf life length for five shrubby Ericaceae in Scandinavia was 1.5-1.6 years, i.e., most second-year leaves did fall off before winter. Other Ericaceae had means nearer to 2.0 or 3.0 years, just as we found that some tree species in SMSF had two or three leaf cohorts in spring (Table 1). For heathland shrubs, as for broad-leaved forest trees, a full interpretation will involve an understanding of the physiology of both the species that lose their leaves before winter and those that keep them until the following spring.

Leopold [45] noted that around his home in Wisconsin, most needles of jack pine (Pinus banksiana), red pine (P. resinosa) and white pine ( $P$. strobus) fall in November, those of the first species being 1.5 years old and those of the other two 2.5 years old. However, for the last two species, Gower et al. [46] reported that in their study area in another part of Wisconsin, the mean longevities equate to an exact number of years or close to one: 36 months for Pinus strobus and 46 for P. resinosa. There is clearly a need to understand not only variation between species in a vegetation type, but also variation within species.

\section{Conclusions}

More attention should be paid to the seasonal timing of leaf fall from evergreen trees and shrubs that experience water shortage resulting from a lack of rain or prolonged cold weather in winter. The available evidence suggests that many of the leaves of such species fall soon after their second summer before conditions become significantly unfavourable, but observations on more species are needed, coupled with critical physiological measurements and experiments.

\section{Acknowledgements}

We thank Ross Dennis for producing the Figures and Peter Baxter, David Chamberlain, Richard Kobe, Philip Rundel, Edmund Tanner, Sarah Wharton, the late Peter Wharton, Wendy Whitmore and Zhekun Zhou for other help.

\section{Author Contributions}

Peter J. Grubb made the observations in China and the study of the numbers of cohorts of old leaves in spring on plants in cultivation in Scotland. Christine L. Thompson and Geoffrey H. Harper made the longer-term observations on leaf fall from five Rhododendron species in cultivation in Scotland. The three authors are jointly responsible for the analysis and presentation of the results and the discussion.

\section{Conflict of interest}

The authors declare no conflict of interest.

\section{References}

1. Kikuzawa, K.; Lechowicz, M.J. Ecology of Leaf Longevity; Springer: Tokyo, Japan, 2011. 
2. Small, E. Photosynthetic Rates in Relation to Nitrogen Cycling as an Adaptation to Nutrient Deficiency in Peat Bog Plants. Can. J. Bot. 1972, 50, 2227-2233.

3. Chabot, B.F.; Hicks, D.J. The Ecology of Leaf Life Spans. A. Rev. Ecol. System. 1982, 13, 229-259.

4. Escudero, A.; Del Arco, J.M.; Garrido, M.V. The Efficiency of Nitrogen Retranslocation from Leaf Biomass in Quercus ilex Ecosystems. Vegetatio 1992, 99/100, 225-237.

5. Mediavilla, S.; Escudero, A. Leaf Life Time Differs from Retention Time of Biomass and Nutrients in the Crowns of Evergreen Species. J. Ecol. 2003, 17, 541-548.

6. Wright, I.J.; Reich, P.B.; Westoby, M.; Ackerly, D.D.; Baruch, Z.; Bongers, F.; Cavender-Bares, J.; Chapin, T.; Cornelissen, J.H.C.; Diemer, M.; Flexas, J.; Garnier, E.; Groom, P.K.; Gulias, J.; Hikosaka, K.; Lamont, B.B.; Lee, T.; Lee, W.; Lusk, C.; Midgley, J.J.; Navas, N.-L.; Niinemets, Ü.; Oleksyn, J.; Osada, N.; Poorter, H.; Poot, P.; Prior, L.; Pyankov, P.I.; Roumet, C.; Thomas, S.C.; Tjoelker, M.G.; Veneklaas, E.J.; Villar, R. The Worldwide Leaf Economics Spectrum. Nature 2004, 428, 821-827.

7. Marty, C.; Lamaze, T.; Pornon, A. Leaf Life-span Optimises Annual Biomass rather than Plant Photosynthetic Capacity in an Evergreen Shrub. New Phytol. 2010, 187, 407-416.

8. Suehiro, K.; Kameyama, K. Leaf Age Composition of Evergreen Broadleaved Trees. Jap. J. Ecol. 1992, 42, 137-147. (In Japanese with English Synopsis)

9. Reich, P.B.; Uhl, C.; Walters, M.B.; Prugh, L.; Ellsworth, D.S. Leaf Demography and Phenology in Amazon Rain Forest: A Census of 40,000 Leaves of 23 Species. Ecol. Monogr. 2004, 74, 3-23.

10. Nitta, I.; Ohsawa, M. Leaf Dynamics and Shoot Phenology of Eleven Warm-Temperate Evergreen Broad-Leaved Trees Near Their Northern Limit in Central Japan. Plant Ecol. 1997, 130, 71-88.

11. Rapp, M. Production de Litière et Apport au Sol d'Eléments dans Deux Écosystèmes Méditerranéens: La Forêt de Quercus ilex L. et la Garigue de Quercus coccifera L. Oecol. Plant 1969, 4, 377-410.

12. Diamantoglou, S.; Mitrakos, K. Leaf longevity in Mediterranean evergreen sclerophylls. In Components of Productivity of Mediterranean-Climate Regions-Basic and Applied Aspects; Margaris, N.S., Mooney, H.A., Eds.; Junk: The Hague, Netherlands, 1981; pp.17-19.

13. Floret, C.; Galan, M.J.; Floc'h, E.L.; Leprince, F.; Romane, F. France. In Plant Pheno-Morphological Studies in Mediterranean Type Ecosystems; Orshan, G., Ed.; Kluwer: Dordrecht, The Netherlands, 1989; pp. 9-97.

14. Castro-Díez, P.; Montserrat-Martí, G. Phenological Patterns of Fifteen Mediterranean Phanerophytes from Quercus ilex Communities in NE-Spain. Plant Ecol. 1998, 139, 103-112.

15. Montserrat-Martí, G.; Pérez-Rontomé, C. Fruit Growth Dynamics and their Effects on the Phenological Pattern of Native Pistacia populations in NE Spain. Flora 2002, 197, 161-174.

16. Escudero, A.; Del Arco, J.M.; Sanz, I.C.; Ayala, J. Effects of Leaf Longevity and Retranslocation Efficiency on the Retention Time of Nutrients in the Leaf Biomass of Different Woody Species. Oecologia 1992, 90, 80-87.

17. Grubb, P.J.; Bellingham, P.J.; Kohyama, T.S.; Piper, F.I.; Valido, A. Disturbance Regimes, Gap-demanding Trees and Seed Mass Related to Tree Height in Warm Temperate Rain Forests Worldwide. Biol. Rev. 2013, 88, 701-744.

18. Walter, H.; Lieth, H. Klimadiagrammen-Weltatlas; Fischer: Jena, Germany, 1960-1967; p. 4. 
19. Hijmans, R.J.; Cameron, S.E.; Parra, J.E.; Jones, P.G.; Jarvis, A. Very High Resolution Interpolated Climate Surfaces for Global Land Areas. Int. J. Climatol. 2005, 25, 1965-1978.

20. Wu, C.Y. Vegetation of Yunnan; Science Press: Beijing, China, 1987; pp. 231-274. (In Chinese).

21. Song, Y. The Essential Characteristics and Main Types of the Broad-leaved Evergreen Forest in China. Phytocoenologia 1988, 16, 105-123.

22. Wu, Z.Y.; Raven, P.H.; Hong, D.Y. Flora of China; Science Press: Beijing, China; Missouri Botanical Garden Press: St Louis, MO, USA, 1996-2008; Volumes 4, 7, 11-15, 19.

23. Stevens, P.F. Angiosperm Phylogeny Website. Available online: www.mobot.org/MOBOT/ resarch/APWeb/ (accessed on 21 July 2014).

24. Fang, M.; Fang, R.; He, M.; Hu, L.; Yang, H.; Chamberlain, D.F. Rhododendron. In Flora of China, Volume 14; Wu, Z.Y., Raven, P.H., Hong, D.Y., Eds.; Science Press: Beijing, China; Missouri Botanical Garden Press: St Louis, MO, USA, 2005; pp. 260-455.

25. Nilsen, E.T. Quantitative Phenology and Leaf Survivorship of Rhododendron maximum L. in Contrasting Irradiance Environments of Southern Appalachian Mountains. Amer. J. Bot. 1986, 72, $822-831$.

26. Nilsen, E.T.; Sharifi, M.R.; Rundel, P.W. Leaf Dynamics in an Evergreen and a Deciduous Species with Even-aged Leaf Cohorts from Different Environments. Amer. Midl. Nat. 1987, 118, 46-55.

27. Lancaster, R. Travels in China. A Plantsman's Paradise; Antique Collector's Club: Woodbridge, UK, 1989; pp. 198-208.

28. Kusomoto, T. Physiological and Ecological Studies on the Plant Production in Plant Communities. 3. Ecological Consideration of the Temperature-Photosynthesis Curves of Evergreen Broad-leaved Trees. Jap. J. Ecol. 1957, 7, 126-130. (In Japanese with English summary)

29. Kusomoto, T. Photosynthesis and respiration in leaves of main component species. In JIBP Synthesis, Vol. 18, Biological Production in a Warm-Temperate Evergreen Oak Forest of Japan; Kira, T., Ono, Y., Hosokawa, T. Eds.; University Press: Tokyo, Japan, 1978; pp. 88-98.

30. Larcher, W. Jahresgang des Assimilations- und Respirationsvermögens von Olea europaea L. ssp. sativa Hoff. et Link., Quercus ilex L., und Quercus pubescens Willd. aus dem nördlichen Gardaseegebiet. Planta 1961, 56, 575-606.

31. Larcher, W. Assimilationsökologie der immergrünen Olea europea und Quercus ilex und der sommergrünen Quercus pubescens im nördlichen Gardaseegebiet. Planta 1961, 56, 607-617.

32. Meletiou, M.S.; Rhizopolou, S.; Diamantoglu, S. Seasonal Changes in Carbohydrates, Lipids and Nitrogen Content in Sun and Shade Leaves from Four Mediterranean Evergreen Sclerophylls. Environm. Exp. Bot. 1994, 34, 129-140.

33. Körner, C. Carbon Limitation in Trees. J. Ecol. 2003, 91, 4-17.

34. Oliveira, G.; Peñuelas, J. Effects of Winter Cold Stress on Photosynthesis and Photochemical Efficiency of PSII of the Mediterranean Cistus albidus L. and Quecus ilex L. Pl. Ecol. 2004, 175, 179-191.

35. Varone, L.; Gratani, L. Physiological Response of Eight Mediterranean Maquis Species to Low Air Temperatures During Winter. Photosynthetica 2007, 45, 385-391.

36. Ayub, G.; Smith, R.A.; Tissue, D.T.; Atkin, O.K. Impacts of Drought on Leaf Respiration in Darkness and Light in Eucalyptus saligna Exposed to Industrial-age Atmospheric $\mathrm{CO}_{2}$ and Growth Temperatures. New Phytol. 2011, 190, 1003-1018. 
37. Galmés, J.; Ribas-Carbó, M.; Medrano, H.; Flexas, J. Response of Leaf Respiration to Water Stress in Mediterranean Species with Different Growth Forms. J. Arid Environ. 2007, 68, 206-222.

38. Gratani, L.; Varone, L.; Catoni, R. Relationship between Net Photosynthesis and Leaf Respiration in Mediterranean evergreen species. Photosynthetica 2008, 46, 567-573.

39. Metcalfe, D.B.; Lobo-Vale, R.; Chaves, M.M.; Maroco, J.P.; Aragao, L.E.O.C.; Malhi, Y.; Da Costa, A.L.; Braga, A.P.; Gonçalves, P.L.; de Athydes, J.; Da Costa, M.; Almeida, S.S.; Campbell, C.; Hurry, V.; Williams, M.; Meir, P. Impacts of Experimentally Imposed Drought on Leaf Respiration and Morphology in an Amazon Rain Forest. Funct. Ecol. 2010, 24, 524-533.

40. Kimura, M.; Suzuki, J.; Tachibana, M.; Tahara, H. Role of Evergreen Foliage in the Nitrogen Economy during Shoot Growth of Ternstroemia gymnanthera, a Warm-Temperate Broadleaf Tree. Bot. Mag. Tokyo 1983, 96, 75-83.

41. Yamamura, Y. Matter-economical Roles of the Evergreen Foliage of Aucuba japonica, an Understory Shrub in Warm-Temperate Region of Japan. 1. Leaf Demography, Productivity and Dry Matter Economy. Bot. Mag. Tokyo 1986, 99, 323-332.

42. Minoletti, M.L.; Boerner, R.E. J. Drought and Site Fertility Effects on Foliar Nitrogen and Phosphorus Dynamics and Nutrient Resorption by the Forest Undershrub Viburnum acerifolium L. Amer. Midl. Nat. 1994, 131, 109-119.

43. Kramer, P.J. Plant and Soil Water Relationships: A Modern Synthesis; McGraw-Hil: New York, NY, USA, 1969; pp. 198-200.

44. Karlsson, P.S. Leaf Longevity in Evergreen Shrubs: Variation Within and Among European Species. Oecologia 1992, 91, 346-349.

45. Leopold, A. A Sand County Almanac and Sketches Here and There; Oxford University Press: New York, NY, USA, 1949; p. 87.

46. Gower, S.J.; Reich, P.B.; Son, Y. Canopy Dynamics and Aboveground Production of Five Tree Species with Different Leaf Longevities. Tree Physiol. 1993, 12, 327-345.

(C) 2014 by the authors; licensee MDPI, Basel, Switzerland. This article is an open access article distributed under the terms and conditions of the Creative Commons Attribution license (http://creativecommons.org/licenses/by/4.0/). 